\title{
Fostering Civic Identity in Architectural Technology Students through the Evaluation of Critical Reflection in Service Learning Coursework
}

\author{
Beth Huffman, Indiana University Purdue University, Indianapolis \\ Beth Huffman is a lecturer at Indiana University Purdue University Indianapolis (IUPUI) in the interior \\ design department. She is a licensed architect with specialties in sustainability and construction. Beth's \\ classroom pedagogy is focused on the practices of design/ build. She often encourages students to build \\ a portion of their projects at full scale, in order to understand construction connections and details. \\ Beth has her Master's of Science degree in Architecture from the Illinois Institute of \\ Technology and her Bachelor's of Architecture degree from Ball State University. Additionally, \\ she continues to practice architecture through her own company, Muse Design. She enjoys \\ the synergistic relationship between her role as a professor and her role as an architect, and \\ believes that this hybrid provides real world practicality into the classroom on a daily basis.
}

Mrs. Kathryn Elizabeth Roche

This is the author's manuscript of the article published in final edited form as:

Huffman, B., \& Roche, K. E. (2018). Fostering Civic Identity in Architectural Technology Students through the Evaluation of Critical Reflection in Service Learning Coursework. Presented at the 2018 ASEE Annual Conference \& Exposition. Retrieved from https://peer.asee.org/fostering-civic-identity-in-architectural-technology-students-throughthe-evaluation-of-critical-reflection-in-service-learning-coursework 


\section{Fostering Civic Identity in Architectural Technology Students through the Evaluation of Critical Reflection in Service Learning Coursework}

Abstract:

This case study follows a semester long, commercial construction course in architectural technology. Students worked both individually and as a class to transform an existing residential structure into a mixed use building for a predominantly commercial use. The semester project was an existing house in a local, urban neighborhood, which is owned by the community partner. The non-profit organization wished to repurpose the house to a mixed-use commercial building, which would house art gallery space on the main level, as well as both short term and long term residences on the second floor. Students spent the entire semester to work through the design process, from field verification, to project programming, all the way through to construction documents, to create a code compliant and aesthetically pleasing building design solution.

The authors seek to document from both the student and professor's perspective, the progress in students' civic identity, through artifacts collected which centered on values, attitudes, and/or beliefs. The student's perspective will focus on her personal involvement, architectural technology related project deliverables and perceived academic outcomes, while the professor's perspective will focus on the development of the students' increased civic identity through the use of meaningful reflection. Lastly, the authors will conclude by extrapolating this experience to other disciplines and applications.

Service Learning /Civic Mindedness Background:

"Two principles define the essence of service learning. The hallmark of pedagogy is reflection: What intellectual underpinnings inform the process and how is the field experience used to challenge and refine this thinking? The crux of engagement is reciprocity: What did the students learn and how did the community benefit; or, conversely, what did the community learn and how did the students benefit?" (Harden, 2006) Regardless of discipline, effective course design and project selection is paramount for success in any service learning class. When beginning the selection of a community partner for a semester project, the author first seeks to follow the six guidelines, as set forth by The Center for Service and Learning at Indiana University Purdue University Indianapolis (IUPUI).

1) Reciprocal partnerships and processes shape the community activities and course design.

2) Community activities enhance academic content, course design, and assignments.

3) Civic competencies (knowledge, skills, disposition, and behavior) are well integrated into student learning.

4) Diversity of interactions and dialogue with others across difference occurs regularly in the course.

5) Critical reflection is well integrated into student learning

6) Assessment is used for course improvement.

While each community project comes with its specific set of advantages and disadvantages, evaluating reciprocity before engaging with a community partner has the potential to alleviate 
conflict for the duration of the project. Once a community project and partner have been prudently chosen, Sutton suggests the following transformative strategies to utilize in service learning pedagogy: "cumulative exposures, comprehensive experiences, capstone experiences, immersion experiences, interdisciplinary experiences, community participation, youth participation, reflective practice, long term participation, and institutional participation" (Sutton 2012). While this is a lengthy list of strategies, not all of these concepts can be applied to a single course, as several are realized over the duration of one's academic career. The strategies most applicable to this paper are immersion experiences and reflective practice, due to the duration of this particular community engaged project.

Moreover, the Civic-Minded Graduate Model "identifies the specific knowledge, skills, and dispositions to describe how students develop civic-mindedness. This model pulls from multiple disciplines, including, but not limited to, student development, social psychology, political and environmental science, and philanthropy. Conceptual Framework for Civic Minded Graduate includes: identity, educational experiences and civic experiences. Included in this framework are: knowledge, skills, dispositions and behavioral intentions." (Weiss, 2017) Figure 1 provides a graphically annotated example of civic mindedness to further illustrate this complicated formation process.

Given the complexities of civic mindedness, the authors are choosing to focus their efforts solely on the domain of civic identity. Through the engagement with a local non-profit organization, students were given the opportunity to exercise their ability to work with others from a different perspective, and reflect on how this engagement impacted each of them personally.

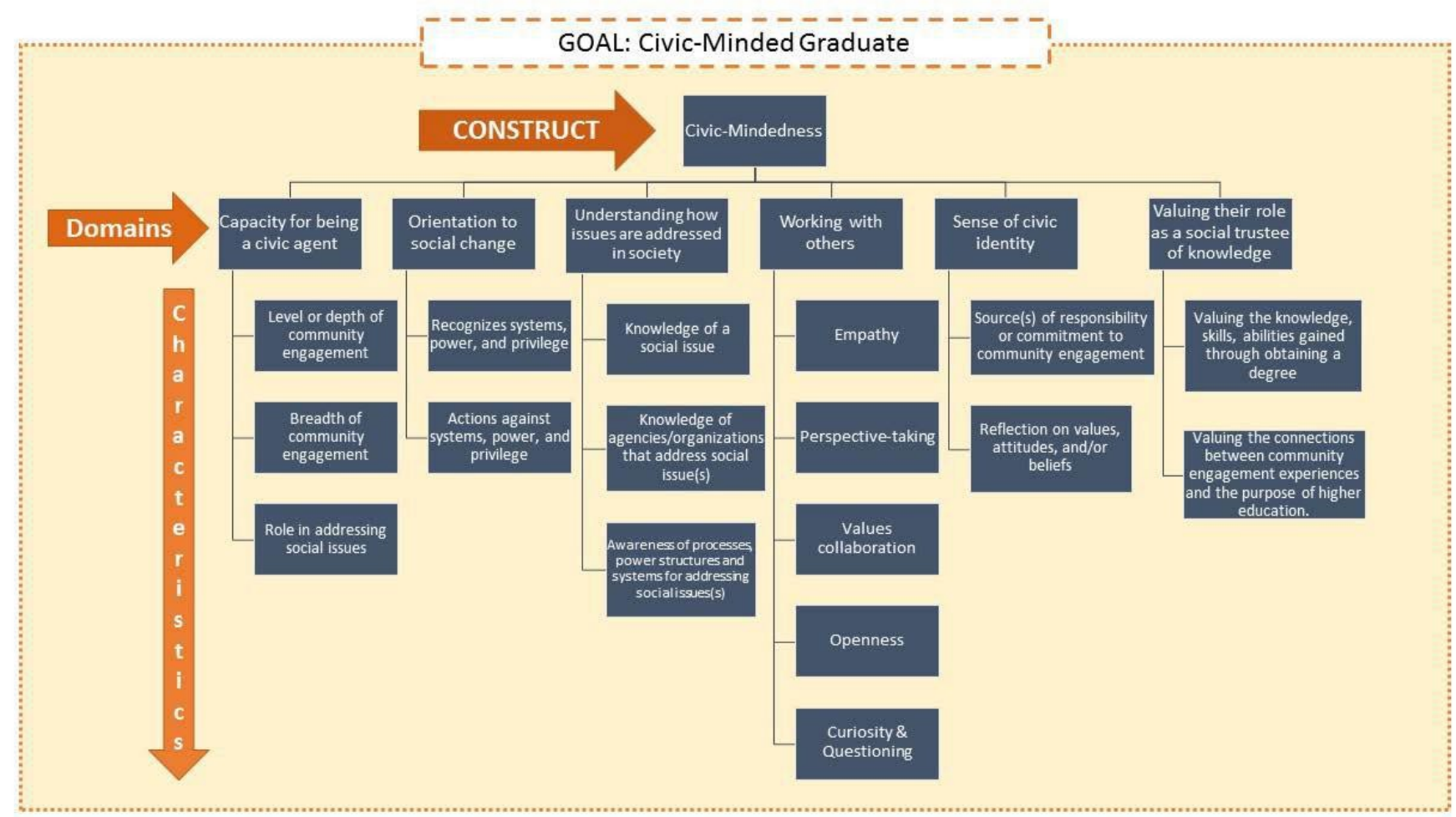

Figure 1: Civic Minded Graduate Rubric 


\section{Architectural Technology Course Artifacts:}

At the beginning of the semester, students visited the existing project site to measure, analyze, and document all of the building's existing conditions. The community partner was present during this visit, and provided insight about what was desired for the future design. The client also mentioned strengths and weaknesses about the existing spaces, and further explained the community partner's mission and goals.

Next, the students spent several weeks drawing the existing building in a building information modeling software program, while also completing a thorough building code study. Students were tasked with completing a building design that was both functional and aesthetically pleasing. Students also had to develop a one word concept, which could be seen in all dimensions of the project. Figure 2 provides an example of a concept board, as created by one student.

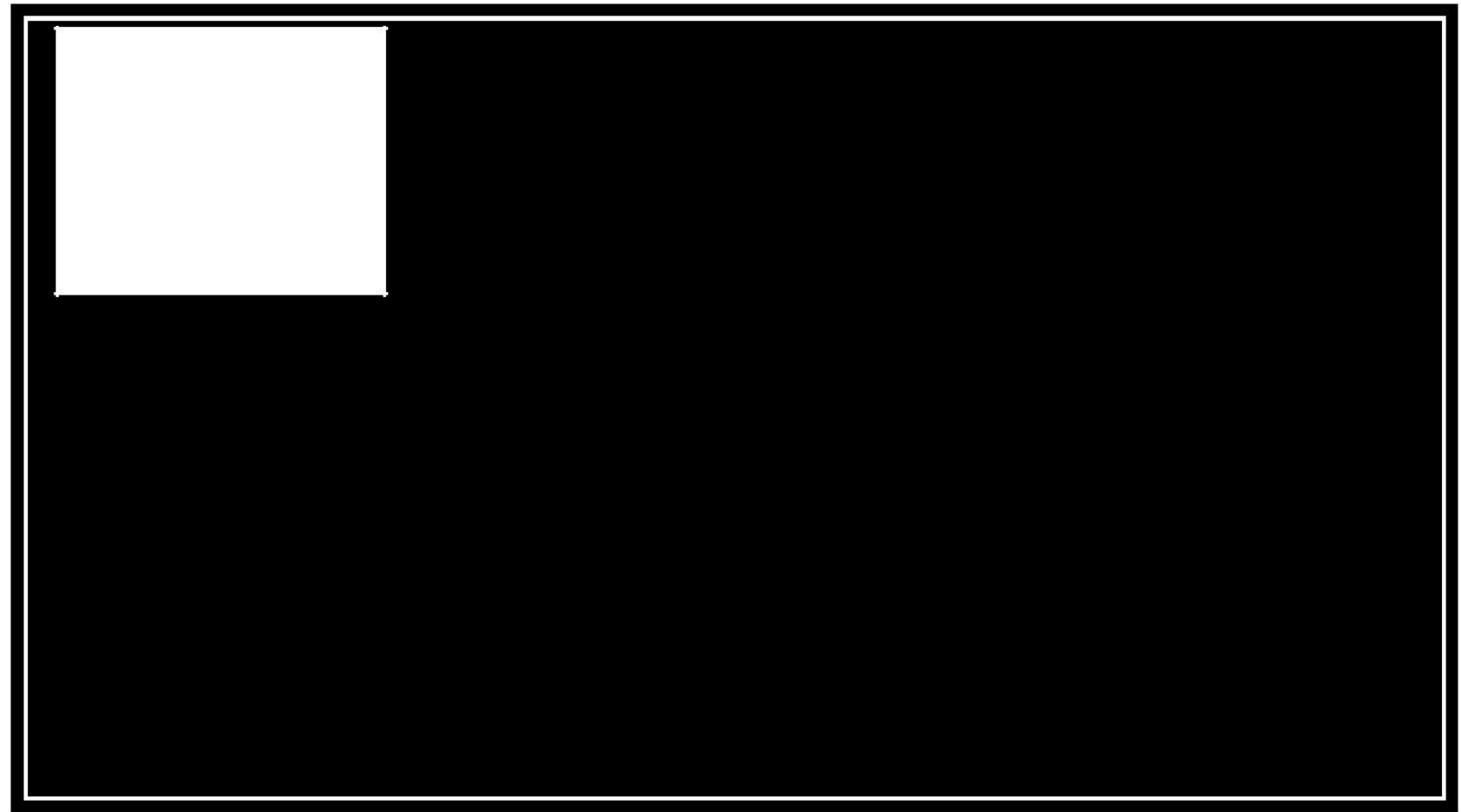

Figure 2: Example of Student Conceptual Work

Once the students completed a building code study, to ensure code compliance, the class met with the community partner to present preliminary color plans. Students received critique from the client regarding both positive and negative aspects of their designs. Students were also able to ask the client clarifying questions to ensure proper direction for the duration of the semester. Figures 3 and 4 illustrate examples of student color plans, which were presented during the preliminary design presentation to the community partner. 


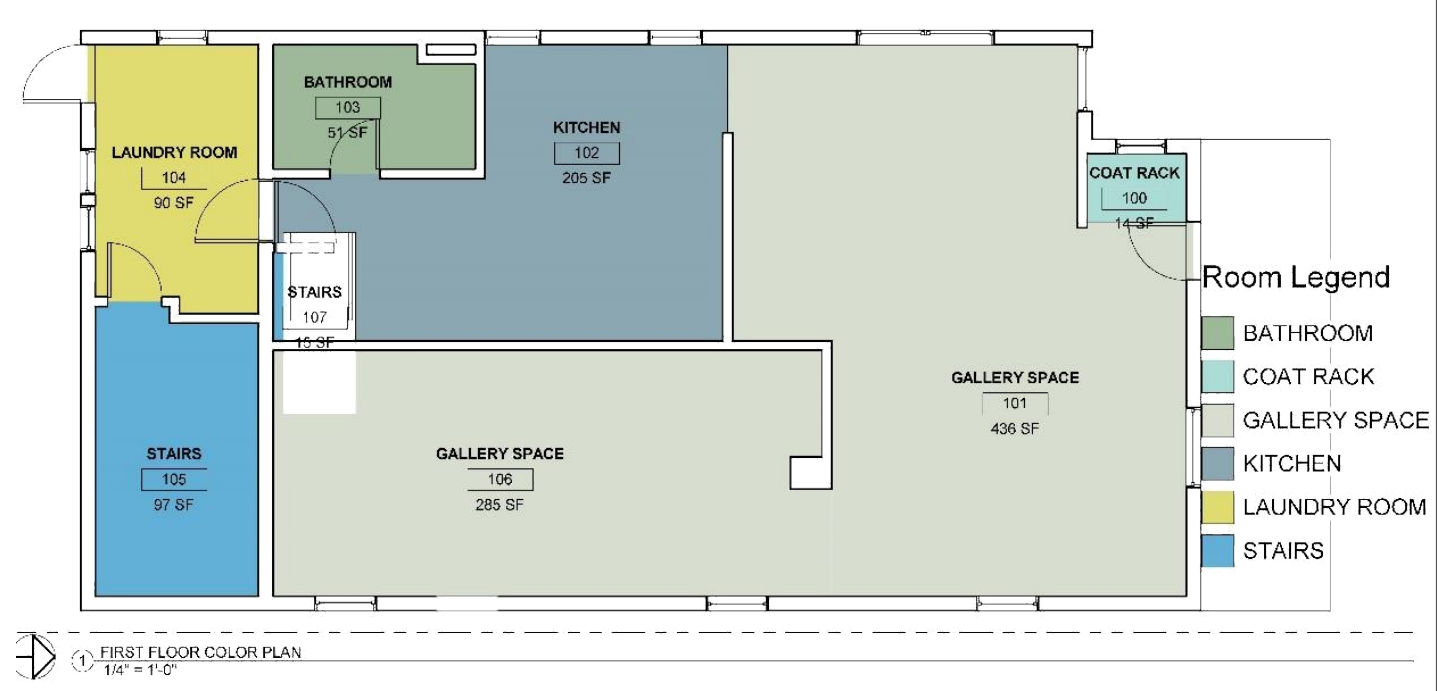

Figure 3: Example of Student Schematic Work

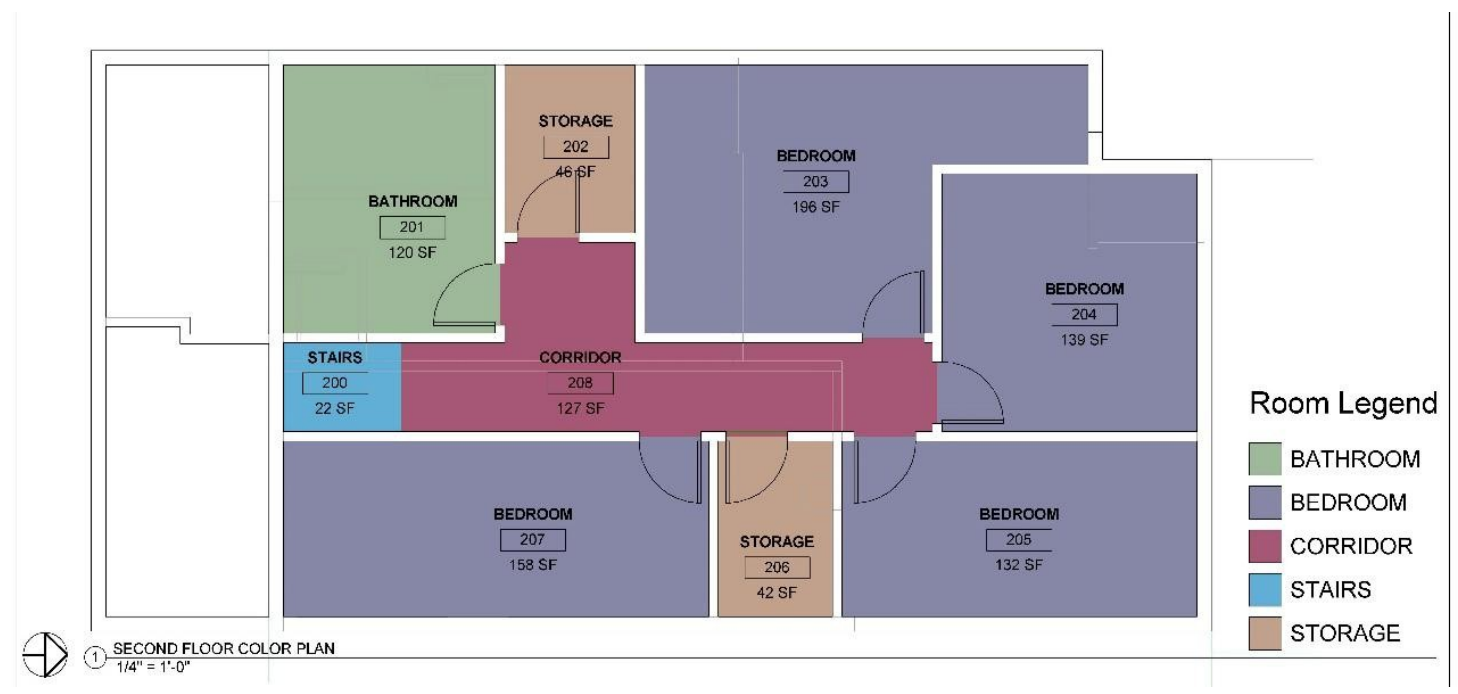

Figure 4: Example of Student Schematic Work

Students then spent the last half of the semester implementing the client changes and developing final deliverables for the semester project. Required deliverables, at the end of the semester, included: a completed building code study, a life safety plan, floor plans, reflected ceiling plans, exterior and interior renderings, and building elevations. The semester ended with a final client presentation, where students individually presented their refined, finalized drawings and models for the client. 

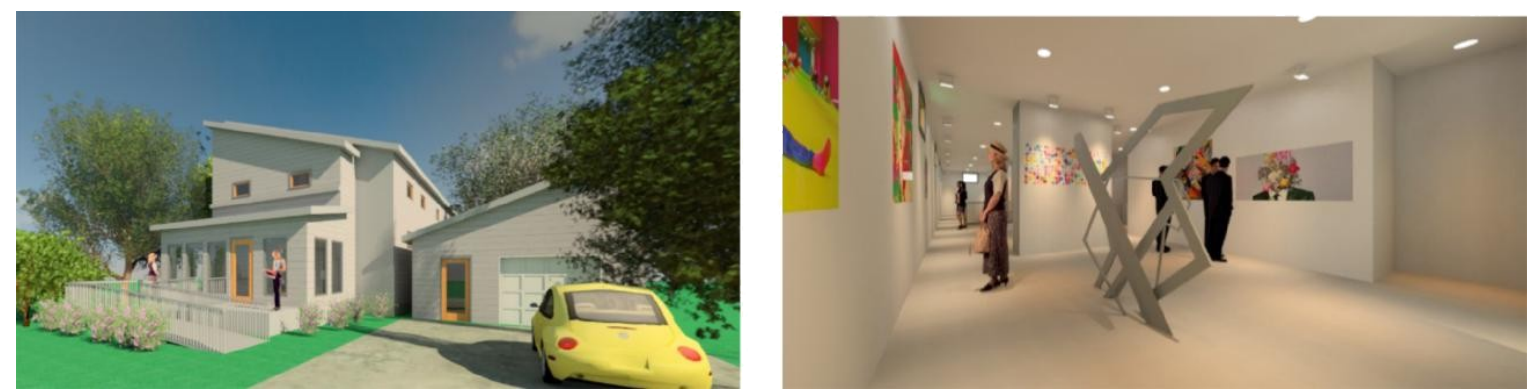

Figure 5: Example of Student Final Deliverables

\section{Critical Reflection Artifacts:}

In addition to the course artifacts listed above, which focused on the architectural learning outcomes, students were also tasked with completing several reflective essays and journal entries which focused on personal experiences and growth. Students also completed digital stories at the semester's close, which highlighted with music, voice and images what they learned through this service learning project. "Digital storytelling is trumpeted as a useful tool in the promotion of deep learning. Deep learning, as opposed to surface learning, is a term used to describe the kind of learning process that involves the critical analysis of new ideas and linking them to already known concepts and principles, which leads to understanding and long-term retention of concepts so that they can be used for problem solving in unfamiliar contexts." (Boase 2008) Listed below are the following prompts given during various milestones throughout the semester.

Journal 1: Describe service learning in your own words. Also describe how working with a real client might impact your learning this semester.

Journal 2: In the first paragraph, describe what you have learned about the client's organization and their values. In the second paragraph, describe what you have discovered through your research about the wants and needs of potential users of the space. Potential users are a residence for visiting artists and visitors for an art gallery.

Journal 3: Write two typed paragraphs explaining your one word design concept. Please explain how this concept reinforces our client's values and mission in the first paragraph, and provide specific examples how your design will reflect your one word concept in the second paragraph.

Journal 4: The first paragraph will include the three most valuable points of feedback you received while presenting your color plans to our clients. The second paragraph will describe tangible ways you are going to incorporate their feedback moving forward with your design.

Journal 5: What have you learned about yourself? What have you learned about your community? What have you contributed to the community site? What values, opinions, beliefs have changed? What was the most important lesson learned? How have you been challenged? What should others do about this issue? What impact did you have on the community?

Digital Storytelling Prompt: A Digital Story is a digital video clip, told in the author's own voice, illustrated mostly with still images, with a musical track added for emotional effect. For this 
course, the digital story should capture your narrative of what you have learned from your service learning experience, and how this might impact your future personal or professional life. Your story should focus on ONE of the following subjects: Biggest lessons learned throughout the semester, or the concept, development and completion of your semester project.

\section{Critical Reflection Coding and Analysis Method}

While there were five journal assignments and one digital storytelling assignment completed during the semester, the authors chose to analyze Journal Assignment \#1 and Journal Assignment \#5. The first assignment was completed in the first two weeks of the semester and acts as a baseline to assess students' understanding of service learning and civic identity. The end of the semester journal entry allows students to demonstrate their growth, academically, civically and personally, as a result of the service learning project.

The authors chose to utilize thematic coding to categorize and analyze the qualitative data, as outlined under the domain of civic identity in the Civic Minded Graduate Rubric 2.0. Figure 6 is a reproduction of the qualitative metric. (Weiss, 2017)

\begin{tabular}{|c|c|c|c|c|c|}
\hline \multirow{3}{*}{$\begin{array}{l}\text { Sense of } \\
\text { Civic } \\
\text { Identity }\end{array}$} & Characteristics & 0-1 Beginner & $\begin{array}{c}2-3 \\
\text { Developing }\end{array}$ & $\begin{array}{c}4-5 \\
\text { Competent }\end{array}$ & 6-7 Accomplished \\
\hline & $\begin{array}{c}\text { Source of } \\
\text { responsibility } \\
\text { or } \\
\text { commitment } \\
\text { to community } \\
\text { engagement }\end{array}$ & $\begin{array}{l}0-1 \text { Little to } \\
\text { no sense of } \\
\text { responsibility } \\
\text { to commit } \\
\text { time, talent } \\
\text { or resources } \\
\text { to ways that } \\
\text { make a } \\
\text { difference in } \\
\text { the } \\
\text { community. }\end{array}$ & $\begin{array}{l}\text { 2-3 Source of } \\
\text { responsibility } \\
\text { is derived } \\
\text { from external } \\
\text { norms, } \\
\text { authority, or } \\
\text { expectations } \\
\text { of others (e.g., } \\
\text { parents, } \\
\text { instructor, } \\
\text { advisor, clubs, } \\
\text { religious } \\
\text { organizations). }\end{array}$ & $\begin{array}{l}\text { 4-5 Source of } \\
\text { responsibility } \\
\text { is derived } \\
\text { from internal } \\
\text { motivations } \\
\text { (i.e., personal } \\
\text { experience, } \\
\text { values and } \\
\text { beliefs, } \\
\text { and/or self- } \\
\text { identified } \\
\text { passions and } \\
\text { interests) }\end{array}$ & $\begin{array}{l}\text { 6-7 Responsibility } \\
\text { and commitment is } \\
\text { derived from a } \\
\text { connection to and } \\
\text { compassion for } \\
\text { community (i.e., no } \\
\text { expectation of } \\
\text { reward or } \\
\text { recognition; not } \\
\text { about personal } \\
\text { accomplishment [s]) }\end{array}$ \\
\hline & $\begin{array}{c}\text { Reflections } \\
\text { on values, } \\
\text { attitudes } \\
\text { and/or beliefs }\end{array}$ & $\begin{array}{l}\text { 0-1 Little to } \\
\text { no reflection } \\
\text { on personal } \\
\text { values, } \\
\text { attitudes, and } \\
\text { beliefs. }\end{array}$ & $\begin{array}{l}\text { 2-3 Aware of } \\
\text { their personal } \\
\text { values, } \\
\text { attitudes, and } \\
\text { beliefs in } \\
\text { relation to } \\
\text { others. }\end{array}$ & $\begin{array}{l}\text { 4-5 Critically } \\
\text { examines } \\
\text { their } \\
\text { personal } \\
\text { values, } \\
\text { attitudes and } \\
\text { beliefs in } \\
\text { relation to } \\
\text { others. }\end{array}$ & $\begin{array}{l}\text { 6-7 Demonstrates } \\
\text { evidence of } \\
\text { adjusting their own } \\
\text { personal values, } \\
\text { attitudes, and } \\
\text { beliefs in relation } \\
\text { to others, while } \\
\text { constructively } \\
\text { challenging the } \\
\text { attitudes, values, }\end{array}$ \\
\hline
\end{tabular}




\begin{tabular}{|l|l|l|l|l|l|}
\hline & & & & & $\begin{array}{l}\text { and beliefs of } \\
\text { others. }\end{array}$ \\
\hline
\end{tabular}

Figure 6: Civic Minded Graduate Rubric 2.0 (Weiss 2017)

\section{Critical Reflection Coding}

Included below is a sample from the students enrolled in the course. Each table provides an initial score for Journal Assignment \#1 based upon the constructs of the Civic Minded Graduate Rubric. Furthermore, the same student was assigned a score for Journal Assignment \#5. Also noted is the change in score from beginning to end of the semester in both characteristics of responsibility to community engagement and reflection on values and attitudes. Lastly, excerpts from the students' journal entries are included in the table as artifacts of the utilized thematic coding method.

\begin{tabular}{|l|l|l|}
\hline Student \#1 & $\begin{array}{l}\text { Source of responsibility or } \\
\text { commitment to community } \\
\text { engagement }\end{array}$ & $\begin{array}{l}\text { Reflections on values, } \\
\text { attitudes and/or beliefs }\end{array}$ \\
\hline Journal 1 & $\begin{array}{l}\text { (2) } \\
\text { "Service Learning to me } \\
\text { means working in a } \\
\text { classroom where the } \\
\text { projects/assignments you do } \\
\text { will either be more } \\
\text { meaningful then just a made } \\
\text { up project or assignment. } \\
\text { These projects/assignments } \\
\text { will be real life examples } \\
\text { with clients that will benefit a } \\
\text { greater good for society" }\end{array}$ & $\begin{array}{l}\text { "Of course when doing a } \\
\text { project for a professor I } \\
\text { would do my best work, but } \\
\text { when given a project to do } \\
\text { with an actual client I feel } \\
\text { more connected to the } \\
\text { project." }\end{array}$ \\
\hline Journal 5 & $\begin{array}{l}\text { (3) } \\
\text { "Not only did I contribute my } \\
\text { ideas but I also contributed } \\
\text { plans for the project. While } \\
\text { thinking farther into the } \\
\text { future we also contributed to } \\
\text { the community by helping } \\
\text { them grow and hopefully } \\
\text { bringing artists to the area } \\
\text { that will hopefully help the } \\
\text { community grow in that area } \\
\text { and hopefully make that area } \\
\text { more aesthetically pleasing } \\
\text { and draw people to that area." }\end{array}$ & $\begin{array}{l}\text { Through this process my } \\
\text { values, opinions and beliefs } \\
\text { didn't change dramatically } \\
\text { although some did sway } \\
\text { throughout the process. It } \\
\text { was my belief before this } \\
\text { project that if a client was } \\
\text { putting in a decent amount of } \\
\text { money or trying to get more } \\
\text { engaged in the process" }\end{array}$ \\
\hline
\end{tabular}




\begin{tabular}{|l|l|l|}
\hline Change & 1 point increase & No change \\
\hline
\end{tabular}

\begin{tabular}{|c|c|c|}
\hline \multicolumn{3}{|l|}{ Student \#2 } \\
\hline Characteristics & $\begin{array}{l}\text { Source of responsibility or } \\
\text { commitment to community } \\
\text { engagement ( } 0-7 \text { scale) }\end{array}$ & $\begin{array}{l}\text { Reflections on values, } \\
\text { attitudes and/or beliefs (0-7 } \\
\text { scale) }\end{array}$ \\
\hline Journal 1 & $\begin{array}{l}\text { (3) } \\
\text { "I am a very social person } \\
\text { who enjoys sharing ideas and } \\
\text { working together in large } \\
\text { group environments. I want to } \\
\text { gain more social and } \\
\text { collaboration skills in order to } \\
\text { apply it in my future when I } \\
\text { actually start working in the } \\
\text { industry with real clients and } \\
\text { co-workers." }\end{array}$ & $\begin{array}{l}\text { (3) } \\
\text { "In this course we will be } \\
\text { having the opportunity to } \\
\text { work with an actual client on } \\
\text { a project. This will be a form } \\
\text { of service learning. In my } \\
\text { own words, service learning } \\
\text { means learning through } \\
\text { volunteering or working with } \\
\text { other community members or } \\
\text { services and applying that to } \\
\text { your own work or skills. } \\
\text { Working with an actual client } \\
\text { this semester will definitely } \\
\text { motivate me to do better in } \\
\text { my work and abilities. It will } \\
\text { allow me to challenge myself } \\
\text { and improve my skills with } \\
\text { working with other people, } \\
\text { and time management." }\end{array}$ \\
\hline Journal 5 & $\begin{array}{l}\text { (5) } \\
\text { "Throughout the course while } \\
\text { completing the semester, I got } \\
\text { a better understanding of who } \\
\text { my community were. } \\
\text { Designing for a real Client } \\
\text { helped me figure that out. } \\
\text { Since we had a real client we } \\
\text { were presenting our design } \\
\text { ideas to, it allowed me to } \\
\text { understand who my } \\
\text { community were. I had to do } \\
\text { research and by doing that I } \\
\text { learned how many people we } \\
\text { have here in the Indianapolis } \\
\text { community who are either } \\
\text { students, workers, or even } \\
\text { less fortunate families. I have } \\
\text { realized there is so much one }\end{array}$ & $\begin{array}{l}\text { (5) } \\
\text { "Overall, the most important } \\
\text { lesson I learned this semester } \\
\text { was that following code is } \\
\text { essential and how to } \\
\text { communicate one's designs } \\
\text { and engage others is a } \\
\text { process. Using this } \\
\text { experience designing and } \\
\text { presenting for a real client, I } \\
\text { now know what to do for } \\
\text { future projects. I know my } \\
\text { strong points as well as weak } \\
\text { points that I need to improve } \\
\text { on in order to be successful in } \\
\text { my designs." }\end{array}$ \\
\hline
\end{tabular}




\begin{tabular}{|l|l|l|}
\hline & $\begin{array}{l}\text { can do as a designer to help } \\
\text { the environment improve and } \\
\text { change." }\end{array}$ & \\
\hline Change & 2 point increase & 2 point increase \\
\hline
\end{tabular}

\begin{tabular}{|c|c|c|}
\hline \multicolumn{3}{|l|}{ Student \#3 } \\
\hline Characteristics & $\begin{array}{l}\text { Source of responsibility or } \\
\text { commitment to community } \\
\text { engagement ( } 0-7 \text { scale) }\end{array}$ & $\begin{array}{l}\text { Reflections on values, } \\
\text { attitudes and/or beliefs (0-7 } \\
\text { scale) }\end{array}$ \\
\hline Journal 1 & $\begin{array}{l}\text { "Working with a client this } \\
\text { semester will be a little } \\
\text { difficult because we have to } \\
\text { meet their requirements on } \\
\text { what they want on this } \\
\text { specific building/space. } \\
\text { Showing them some work } \\
\text { and changing things around } \\
\text { can also be something that } \\
\text { can happen." }\end{array}$ & $\begin{array}{l}\text { (1) } \\
\text { "It will also be good because } \\
\text { I would get the experience to } \\
\text { engage with a client and } \\
\text { know what it is like to work } \\
\text { with him/her." }\end{array}$ \\
\hline Journal 5 & $\begin{array}{l}\text { (2) } \\
\text { "I learned is that the } \\
\text { community is very open to } \\
\text { anything, they say } \\
\text { experiences and with those } \\
\text { experiences they are willing } \\
\text { to help, to lend a hand to ones } \\
\text { that need the help. They were } \\
\text { not selfish about anything, } \\
\text { they were selfless, giving } \\
\text { time out of their time to } \\
\text { help." }\end{array}$ & $\begin{array}{l}\text { (2) } \\
\text { "Things I learned about my } \\
\text { community and/or my class, } \\
\text { is that they will always be } \\
\text { there to help you in whatever } \\
\text { situation you come across in } \\
\text { the class. They will help and } \\
\text { one never knows if they are } \\
\text { having the same issue. That } \\
\text { way you can help each other } \\
\text { to resolve any problem." }\end{array}$ \\
\hline Change & 1 point increase & 1 point increase \\
\hline
\end{tabular}

\begin{tabular}{|l|l|l|}
\hline Student \#4 & \multicolumn{3}{|c|}{$\begin{array}{l}\text { Source of responsibility or } \\
\text { commitment to community } \\
\text { engagement (0-7 scale) }\end{array}$} & $\begin{array}{l}\text { Reflections on values, } \\
\text { attitudes and/or beliefs (0-7 } \\
\text { scale) }\end{array}$ \\
\hline Journal 1 & $\begin{array}{l}\text { (3) } \\
\text { "I have come to conclusion } \\
\text { that Service Learning is a task } \\
\text { given to a student that will }\end{array}$ & $\begin{array}{l}\text { "I) } \\
\text { "I've worked with "clients" } \\
\text { aka classmates in the past, but } \\
\text { have never actually been put } \\
\text { in a situation or given a task } \\
\text { individual or individuals in } \\
\text { in which I have to create } \\
\text { which the task is for. Service } \\
\text { something for an actual } \\
\text { client, so learning how to }\end{array}$ \\
\hline
\end{tabular}




\begin{tabular}{|c|c|c|}
\hline & $\begin{array}{l}\text { scenarios and situations in } \\
\text { which the student will have } \\
\text { the opportunity to apply what } \\
\text { they have learned, learn from } \\
\text { the process/gain experience, } \\
\text { and provide a final product } \\
\text { for the recipient. With the } \\
\text { student taking part in this } \\
\text { Service Learning task, they } \\
\text { are providing a service that } \\
\text { will benefit both ends of the } \\
\text { task." }\end{array}$ & $\begin{array}{l}\text { effectively listen to their } \\
\text { needs and take notes, how to } \\
\text { portray their vision to them } \\
\text { effectively, and learning how } \\
\text { to professionally present to an } \\
\text { actual client are a few things I } \\
\text { am interested in learning." }\end{array}$ \\
\hline Journal 5 & $\begin{array}{l}\text { (4) } \\
\text { "With our class presenting } \\
\text { different unique ideas for this } \\
\text { home, we are putting forward } \\
\text { visual improvements to the } \\
\text { urban neighborhood. This } \\
\text { area still appears to } \\
\text { untouched so far as far as the } \\
\text { changing of home exteriors, } \\
\text { so the possibility that a design } \\
\text { of ours can make it in there } \\
\text { creates the first step to a } \\
\text { creative, new change to the } \\
\text { surrounding area. I feel like } \\
\text { my project and others have } \\
\text { made a large contribution to } \\
\text { the site as well." }\end{array}$ & $\begin{array}{l}\text { (4) } \\
\text { "I believe that others' and my } \\
\text { projects have already made } \\
\text { an impact on the site because } \\
\text { we sparked ideas and } \\
\text { inspirations for the up and } \\
\text { coming project. I am } \\
\text { definitely excited to see what } \\
\text { designs they come up with for } \\
\text { the actual product and I am } \\
\text { excited to see it come } \\
\text { together." }\end{array}$ \\
\hline Change & 2 point increase & 2 point increase \\
\hline
\end{tabular}

\begin{tabular}{|l|l|l|}
\hline Student \#5 & $\begin{array}{l}\text { Source of responsibility or } \\
\text { Commitment to community } \\
\text { engagement (0-7 scale) }\end{array}$ & $\begin{array}{l}\text { Reflections on values, } \\
\text { attitudes and/or beliefs (0-7 } \\
\text { scale) }\end{array}$ \\
\hline Journal 1 & $\begin{array}{l}\text { (3) } \\
\text { "Service learning helps you } \\
\text { learn how to interact with the } \\
\text { job that you are seeking. } \\
\text { Working with an actual client } \\
\text { this semester will greatly } \\
\text { improve my professional } \\
\text { skills but also improve my } \\
\text { skills on how to interact with } \\
\text { something everyone needs a } \\
\text { grip on before they enter the } \\
\text { real world." }\end{array}$ & \\
& brand new clients when I am \\
working in the real world. I & \\
\hline
\end{tabular}




\begin{tabular}{|l|l|l|}
\hline & $\begin{array}{l}\text { will be able to listen and learn } \\
\text { from what they want. I will } \\
\text { be able to make mistakes but } \\
\text { learn from them. Clients are a } \\
\text { great way to improve your } \\
\text { knowledge as well and to } \\
\text { learn from experience with } \\
\text { them for future clients." }\end{array}$ & \\
\hline Journal 5 & $\begin{array}{l}\text { "4) } \\
\text { "I have learned that there are } \\
\text { organizations in our } \\
\text { community who are trying to } \\
\text { revamp neighborhoods and } \\
\text { bring everyone together for a } \\
\text { good purpose. They are } \\
\text { including creativity in their } \\
\text { work and most people are } \\
\text { attracted to that. I believe } \\
\text { they are doing good things } \\
\text { and really want to help the } \\
\text { community." }\end{array}$ & $\begin{array}{l}\text { "I think a belief of mine that } \\
\text { changed was the belief in } \\
\text { this process as a designer and } \\
\text { explored more than I had } \\
\text { known." }\end{array}$ \\
\hline & \begin{tabular}{l} 
1 point increase \\
\hline
\end{tabular} & \\
\hline Change & \\
\hline
\end{tabular}

\begin{tabular}{|l|l|l|}
\hline Student \#6 & $\begin{array}{l}\text { Source of responsibility or } \\
\text { commitment to community } \\
\text { engagement (0-7 scale) }\end{array}$ & $\begin{array}{l}\text { Reflections on values, } \\
\text { attitudes and/or beliefs (0-7 } \\
\text { scale) }\end{array}$ \\
\hline Journal 1 & $\begin{array}{l}\text { (3) } \\
\text { "To me, service learning } \\
\text { means being in direct contact } \\
\text { with the client as you work to } \\
\text { accomplish their needs and } \\
\text { wants. I think working with } \\
\text { an actual client will give me } \\
\text { an invaluable learning } \\
\text { experience in terms of } \\
\text { increasing my } \\
\text { professionalism, work } \\
\text { processes and accurately } \\
\text { achieving the clients' goals. } \\
\text { actual client will give me an } \\
\text { invaluable learning } \\
\text { experience in terms of } \\
\text { increasing my } \\
\text { professionalism, work } \\
\text { processes and accurately } \\
\text { achieving the clients' goals. } \\
\text { Additionally, it will help me } \\
\text { to reframe my way of } \\
\text { thinking about the project } \\
\text { from the beginning. In past, } \\
\text { fictional, projects I approach } \\
\text { the solution from only the } \\
\text { way I think is best or } \\
\text { desirable. However, working } \\
\text { with an actual client will } \\
\text { allow me to understand what }\end{array}$ \\
&
\end{tabular}




\begin{tabular}{|l|l|l|}
\hline & & $\begin{array}{l}\text { will best fit their needs and } \\
\text { intentions. }\end{array}$ \\
\hline Journal 5 & $\begin{array}{l}\text { (6) } \\
\text { "I also learned that I really } \\
\text { enjoyed working with a not- } \\
\text { for-profit community partner, } \\
\text { even though the client } \\
\text { interaction was less that what } \\
\text { I originally anticipated. I } \\
\text { changed after having } \\
\text { completed this project. } \\
\text { Before the project began I } \\
\text { never saw myself working } \\
\text { with community partners in } \\
\text { projects of this caliber in the } \\
\text { future because it is a good } \\
\text { feeling to know that I not } \\
\text { only completed an } \\
\text { assignment for the course but } \\
\text { I am playing a role in helping } \\
\text { career. However, now that I } \\
\text { this organization make the } \\
\text { community better. }\end{array}$ & $\begin{array}{l}\text { worked through this house } \\
\text { renovation with a local non- } \\
\text { andit, I value having created } \\
\text { and built a relationship with } \\
\text { progressive community } \\
\text { organization." }\end{array}$ \\
\hline Change & 3 point increase & 3 point increase \\
\hline
\end{tabular}

\begin{tabular}{|c|c|c|}
\hline \multicolumn{3}{|l|}{ Student \#7 } \\
\hline Characteristics & $\begin{array}{l}\text { Source of responsibility or } \\
\text { commitment to community } \\
\text { engagement ( } 0 \text {-7 scale) }\end{array}$ & $\begin{array}{l}\text { Reflections on values, } \\
\text { attitudes and/or beliefs (0-7 } \\
\text { scale) }\end{array}$ \\
\hline Journal 1 & $\begin{array}{l}\text { "I } \\
\text { "I have never really been that } \\
\text { involved with my } \\
\text { community. It was great to } \\
\text { see how Big Car was } \\
\text { involved with the community. } \\
\text { Their idea of having smaller } \\
\text { art galleries for artists to } \\
\text { showcase their work is a } \\
\text { different idea, but it is very } \\
\text { interesting. I was not aware } \\
\text { that people or companies } \\
\text { were this involved in the } \\
\text { community." }\end{array}$ & $\begin{array}{l}2 \\
\text { "I hope to build a good } \\
\text { relationship with the } \\
\text { professor or even other peers. } \\
\text { Building a relationship is a } \\
\text { great way to network and get } \\
\text { your name out there. The } \\
\text { third thing that I would like to } \\
\text { gain, would be } \\
\text { professionalism. When giving } \\
\text { a presentation sometimes } \\
\text { nerves over take people so I } \\
\text { think practice in front of your } \\
\text { peers and in front of people } \\
\text { you don't know will help. }\end{array}$ \\
\hline Journal 5 & $\begin{array}{l}6 \\
\text { "The only thing I would say } \\
\text { is that I feel it is more } \\
\text { difficult than I imagined to } \\
\text { make change, for I fear that } \\
\text { lasting change can only start }\end{array}$ & $\begin{array}{l}6 \\
\text { "Balancing my ego and } \\
\text { emotional needs for the } \\
\text { project against the client's } \\
\text { personality and needs was a } \\
\text { key lesson that I worked }\end{array}$ \\
\hline
\end{tabular}




\begin{tabular}{|c|c|c|}
\hline & $\begin{array}{l}\text { with deep systemic change } \\
\text { within our society and } \\
\text { addressing adverse } \\
\text { psychological effects on } \\
\text { disadvantaged people. } \\
\text { Without some sort of } \\
\text { emphasis on the emotional } \\
\text { and mental health effects on } \\
\text { disenfranchised people and } \\
\text { neighborhoods, and } \\
\text { improvement of their } \\
\text { economic situation, it will be } \\
\text { difficult for placemaking } \\
\text { goals to be fully } \\
\text { implemented." }\end{array}$ & $\begin{array}{l}\text { through. Acknowledging that } \\
\text { the project was much more } \\
\text { important to me than to them } \\
\text { at this point helped me } \\
\text { process the low input that } \\
\text { they had at the final } \\
\text { presentation, although it } \\
\text { certainly did still feel } \\
\text { awkward." }\end{array}$ \\
\hline Change & 5 point increase & 4 point increase \\
\hline
\end{tabular}

In most cases, this course is the first time students have interacted with service learning in a classroom setting. Students' entries typically reflect their lack of experience with this pedagogy, especially in the first journal entry. The goal of these writings is the help the instructor measure each student's development in civic identity and reflexivity throughout the duration of the semester. Getting the students' initial thoughts also helps the instructor gain insight into what the student's hopes are for the semester.

Of all the entries included above, a common theme among the students is one of increased ownership and responsibility because of the inclusion of a real client. Furthermore, several students mentioned that this experience was sure to provide good practice for industry and post graduate work in the industry. The students' hypotheses were directly in alignment with American Institute of Architects Code of Ethics which states one of their main tenets as "obligation to the public." (AIA 2017).

At the end of the semester, students spend more time reflecting on their experiences from the service learning project. The final class session is spent talking through the strengths and weaknesses of the project and the course. Additionally, the class views each student's digital story, and each student submits a two page narrative to answer the questions posed in Journal Assignment \#5.

A common thread seen from the students of this semester was an increased awareness of the local community, as well as a desire to help the people around them. Additionally, many students stated that the practice of working with an actual design project pushed and motivated them in ways a traditional classroom setting does not. Many also stated the sense of satisfaction they received as a result of this experience was greater than in a traditional classroom setting. Students also had to adapt to designing for someone else's wishes, instead of their own. This is a process that often requires students to be more open and flexible than when designing for a fictitious project. 
Lastly, it is worth noting that each student analyzed show an increase in the characteristics of civic identity from beginning of the semester to the end. While the magnitude of the improvement varied considerably from student to student, each student experienced gains in either or both of the characteristics of civic identity.

Student Perspective:

Our project with a local non-profit organization was the first exposure I have had in completing a design project with a not -for-profit, community partner and it was truly a learning experience. The initial programming phase was intriguing because I was not familiar with our client prior to this project nor did I realize the impact this organization was having in our local community. Learning about how this organization has transformed and revitalized many struggling neighborhoods around the city through their practice of 'placemaking' and 'socially engaged art' was something I knew I wanted to be a part of.

After being introduced to the client, we discussed their wants and needs prior to touring the recently purchased property: a single-family home. The client explained that, as an art-based organization, visiting artists frequently come to the city for limited quantities of time to present art shows, assist with installations as well as host lectures. During these visits, the organization has never had space to offer guests as respite or place in which to stay overnight. Providing a residential dwelling area was a must-have for the client, which included designing a functional and more spacious kitchen, private bedrooms, as well as a designated area for lounging, gathering and eating. Also, having ample space in which to host public functions and art exhibitions was paramount for the client.

The specific project deliverables included: preliminary and finished color plans and perspective renderings for client presentation, Life Safety Plans, Site Plan, Architectural Floor Plans, Reflected Ceiling Plans, Exterior Elevations, Wall Section and accompanying wall legends, door and window schedules, all to be completed at the end of the semester.

The student-client interaction consisted of two client meetings prior to the final presentation. In our first meeting, we met with a staff member of the not-for-profit at the project site to field measure the space as well as discuss the organization's want and needs for the property. Approximately four weeks later, after drafting our initial designs, we were invited back to the client's headquarters, which neighbors the project site, to present our preliminary floor plans and concept ideas to the client. These two meetings were important in that they allowed us to receive some client feedback during the design phase to provide direction for moving forward. Finally, we presented our final design solutions to multiple members of the organization.

Summary and Future Recommendations - Student Perspective

Having the opportunity to present a design in front of clients is always beneficial and will only advance this skill set. However, one change that could have improved the experience of studentclient interaction amongst our community partner was having more than one organizational member present during the initial meetings. Varying feedback would have been helpful and especially that of the organization's co-founder since he was the driving force behind the new 
property in which to be renovated. One con from this limited client interaction was the feeling of information being withheld from the class such as budgetary restrictions and active progress happening with the property. As the designer, this lack of information did present a set of challenges while working towards a functional and affordable design for our community partner. However, a positive of not being privy to budget and construction plans allowed for freedom of creativity throughout the design process, which was refreshing.

I have learned that I thrive and most enjoy client interaction. As a recommendation for future classes, I think increased face-to-face interaction with the client, coupled with increased frequency of meetings, would be beneficial not only for a student's personal and professional development but also to aid in feedback and progress of the project. Additionally, I would decrease the duration of class time spent on general coverage of the IBC. The code was an integral part of this project, but I feel that the IBC started to make more sense when we could apply it directly to our code study for the client's property. Decreasing the time spent on this specific subject would free up more time to work on the construction documents during class, which would be beneficial as they are the most time-consuming aspect.

Learning how to create a full set of detailed, construction drawings is an invaluable skill to acquire as a student entering the architectural and interior design industry, but creating such for a real (versus fictional) client really seemed to emphasize its importance to me. Completing this component of the project required me to critically think about much more than the project's aesthetics, such as how the demolition and new construction phases will work, the appropriate selection of building materials, as well as the overall functionality. Revit software was solely used throughout this course and served as the basis for generating all construction documents, color plans and renderings for this project. Whether students were beginners or experienced in this software, the act of designing a total renovation project, which included troubleshooting complex issues within the program, led to an overall increased technical proficiency with this software. Revit should remain the selected software for such projects and coursework since it is widely used by industry professionals.

For an academic project, the benefits of having an actual client far outweighed the fictional clients with whom we often deal as students. To have had the opportunity to engage with a client that is not only seeking design expertise but who is also working to redevelop a struggling neighborhood, provide art, music and cultural experiences to the community at-large as well as establish an all-inclusive structure to provide artist residences, gallery and event spaces was an educational experience that awakened me to the cultural and social movement happening in my very own city. Through this service learning experience, I learned about placemaking and socially engaged art; two unique concepts practiced by this organization. I became aware of how impactful making spaces for people can be for and within a community. After having been a part of this service-learning course, I hope to work in collaboration with more community partners in the future.

Summary and Future Recommendations - Professor Perspective 
While it is difficult to pinpoint one artifact or experience that most influenced student learning or critical reflection, it is evident that the pedagogies of service learning and community engagement have the ability to drastically impact a student's civic identity. The majority of students were highly motivated to produce a high quality product for the community partner, while also expanding their ability to communicate and discern what a non-profit agency's design needs were. Furthermore, the opportunity for the class to participate in something larger than themselves' certainly encouraged the students to create their best work, while fostering awareness of what is happening in the neighborhoods all around them. In the students' final essays, several mentioned how this experience exposed them to different types of clients and building design, while others mentioned how this had ignited a passion in them to work with the community to bring about change for the greater good.

Overall, the change in students' attitudes regarding community design from their beginning reflections to the last journal assignment, was the biggest change that was recorded. Additionally, the awareness that was gained by working with a local non-profit agency also caused students to reflect on potential career paths upon graduation. Lastly, students also noted how their motivation level was increased because of the inclusion of an actual client.

As evidenced by the included excerpts from the beginning and end of the semester, the students' level of civic identity and critical reflexivity certainly showed positive gains throughout the duration of the semester. The students' understanding of community issues, agencies and needs were certainly better defined as evidenced in the writings.

Each semester, the instructor evolves the number and types of prompts provided, as each class and project are different. While the prompts provided are a starting point, the distributed practice of reflective writing throughout the semester has consistently shown gains in reflexivity every semester. Also, the inclusion of the digital storytelling has been a fantastic addition to promote critical thinking, reflexivity and creativity in architectural technology courses.

During the process of thematic coding and analysis, the authors noticed the student journal assignments varied in level of quality and depth. While there could be numerous reasons for this disparity, the authors recommend narrowing the focus of the prompts provided to potentially encourage more focused results for a chosen construct. Due to the sheer volume of data produced by student journal entries, the use of thematic coding is recommended for the organization and distillation of data. This qualitative research method helped to categorize and quantify the student writings.

\section{Conclusion}

Engaging students in reflective writings in an architectural service learning project was the discipline specific modality chosen for this case study. However, the importance and application extends to various disciplines and can be adapted and utilized in various university settings (Galford 2015). At the center of this case study is a desire to increase the students' civic identity through the characteristics of civic responsibility and reflexivity. Readers are encouraged to extrapolate the reflective prompts and use of digital storytelling for their 
discipline specific content areas. While the experiences and project of this case study maybe specific for design students, the application of exposing students to service learning project with the hope of increasing students' civic identity and critical reflexivity is applicable across various disciplines. 


\section{References}

American Institute of Architects Code of Ethics." Http://aiad8.Prod.acquia-

Sites.com/Sites/Default/Files/2017-08/2017\%20Code\%20Update.Pdf, Feb. 2017, www.bing.com/cr?IG=D9BAF2C20F21422FA0F5F1D91BFA30EA\&CID=046A951440E56F1. F2B8D9EBE414A6E59\&rd=1\&h= Qo0OhJPffdoE30YujLP6ZK8ReJoKfnYdpNUZcSuCxk\&v

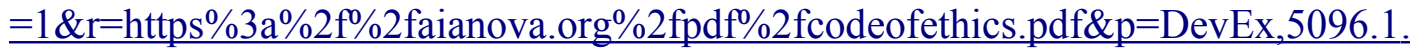

Barrett, H. (2006) Researching and Evaluating Digital Storytelling as a Deep Learning Tool. [Online] http://electronicportfolios.com.Hardin, Mary C., et al. From the Studio to the Streets: Service-Learning in Planning and Architecture. Stylus, 2006.

Boase, C. (2008) Digital storytelling for reflection and engagement, a review of the potential for digital storytelling. Report produced as part of the Phase 1 of The Higher Education Academy / JISC Higher Education e-Learning Pathfinder Programme.

Galford, G., Hawkins, S., \& Hertweck, M. (2015). Problem-Based Learning as a Model for the Interior Design Classroom: Bridging the Skills Divide Between Academia and Practice. Interdisciplinary Journal of Problem-Based Learning, 9(2).

Hatcher, J. A. (2008). The public role of professionals: Developing and evaluating the CivicMinded Professional scale. (Doctoral dissertation). Retrieved from Pro Quest Dissertation and Theses, AAT 3331248.

Steinberg, K. S., Hatcher, J. A., \& Bringle, B. G. (2008) Civic-Minded Graduate: A North Star. Michigan Journal of Community Service Learning, 18, 19-33.

Sutton, Sharon. "Michigan Journal of Community Service Learning." Michigan Journal of Community Service Learning, Vol. 19, No. 1, Fall, 2012 - A Peer-Reviewed Publication | Online Research Library: Questia, Oct. 2012, www.questia.com/library/p408590/michigan-journal-ofcommunity-service-learning/i3192202/vol-19-no-1-fall.

Weiss, H.A., Hahn, T., and Norris, K. (2017). Civic-Minded Graduate 2.0: Assessment Toolbox

Wenning, Mary. "Book Review: Service-Learning in Design and Planning: Educating at the Boundaries. Angotti, Tom, Doble, Cheryl, Horrigan, Paula, Eds. 2011. Service-Learning in Design and Planning: Educating at the Boundaries. Oakland, CA: New Village Press. 305. ISBN 978-1-61332-001-3.” Journal of Planning Education and Research, vol. 33, no. 4, 2013, pp. 499501. 